\title{
Intragraft heme oxygenase-1 and coronary artery disease after heart transplantation
}

\author{
Cecile T.J. Holweg ${ }^{\mathrm{a}, *}$, Aggie H.M.M. Balk ${ }^{\mathrm{b}}$, Jasper Snaathorst ${ }^{\mathrm{a}}$, Sandra van den Engel ${ }^{\mathrm{a}}$, \\ Hubert G.M. Niesters ${ }^{\mathrm{c}}$, Alex W.P.M. Maat ${ }^{\mathrm{d}}$, P.E. Zondervan ${ }^{\mathrm{e}}$, Willem Weimar ${ }^{\mathrm{a}}$, Carla C. Baan ${ }^{\mathrm{a}}$ \\ ${ }^{a}$ Erasmus MC, University Medical Center Rotterdam, Department of Internal Medicine, Room Ee559, Dr Molewaterplein 50, \\ 3015 GE Rotterdam, The Netherlands \\ ${ }^{\mathrm{b}}$ Department of Cardiology, Erasmus MC, Rotterdam, The Netherlands \\ ${ }^{c}$ Diagnostic Institute of Molecular Biology, Erasmus MC, Rotterdam, The Netherlands \\ ${ }^{\mathrm{d} D e p a r t m e n t ~ o f ~ T h o r a c i c ~ S u r g e r y, ~ E r a s m u s ~ M C, ~ R o t t e r d a m, ~ T h e ~ N e t h e r l a n d s ~}$ \\ ${ }^{\mathrm{e}}$ Department of Pathology, Erasmus MC, Rotterdam, The Netherlands
}

Received in revised form 11 August 2004; accepted 18 August 2004

\begin{abstract}
Peri-operative tissue injury triggers the development of Transplant Coronary Artery Disease (TCAD). Animal studies have shown that induction of heme oxygenase (HO)-1 protects the donor organ from the development of TCAD. To investigate the role of HO-1 in TCAD after clinical heart transplantation, we measured intragraft mRNA expression of HO-1, HIF-1 $\alpha$, TGF- $\beta$, FLIP, and the Bcl-2/Bax balance. Immunohistochemical staining of HO-1 was performed to determine its origin. Myocardial biopsies taken at the end of the transplantation procedure (time 0 ), at 1 week and at 10 months after transplantation were studied from recipients with or without angiographic signs of accelerated TCAD, diagnosed after 1 year. At time 0 , no differences in mRNA expression for any of the measured parameters were found between TCAD positive and negative patients. At 1 week, mRNA expression of HO- 1 and TGF- $\beta$ was higher in grafts that developed accelerated TCAD ( $p=0.001$ and $p=0.0002)$. These higher mRNA levels were accompanied by a pro-apoptotic shift in $\mathrm{Bcl}-2 / \mathrm{Bax}(p=0.02)$, suggesting proneness for apoptosis via the mitochondrial pathway. Immunohistochemical staining showed that HO-1 was mainly produced by infiltrating macrophages. At 10 months, again HO- 1 and TGF- $\beta$ levels were high in TCAD positive patients $(p=0.02$ and $p=0.05)$, but the expression of apoptotic markers was comparable at this time point. Our results suggest that a higher HO-1 by macrophages in our patient population might be an adaptive response to tissue injury and inflammation, reflecting damage due to the transplantation procedure that finally results in TCAD.
\end{abstract}

(C) 2004 Elsevier B.V. All rights reserved.

Keywords: Cardiac transplantation; Coronary disease; Inflammation; Adaptive response; Heme Oxygenase-1

\section{Introduction}

Transplant coronary artery disease (TCAD) is the cause of morbidity and mortality in a considerable number of heart transplant recipients [1]. TCAD is a chronic inflammatory process characterized by progressive and diffuse intimal thickening, due to migration of macrophages, migration and proliferation of T-cells and smooth muscle cells, collagen

\footnotetext{
* Corresponding author. Tel.: +31 10 4635420; fax: +31 104089443

E-mail address: cholweg@cvmed.stanford.edu (C.T.J. Holweg).
}

accumulation and fibrosis [2]. Oxidative stress due to perioperative ischemia followed by reperfusion might be an early trigger for TCAD $[2,3]$. Oxidative stress leads to apoptosis and necrosis of endothelial cells, vascular smooth muscle cells and cardiac myocytes. This could subsequently result in activation of cytokines and growth factors, like IFN- $\gamma$, PDGF- $\alpha$, bFGF and TGF- $\beta$, that are involved in processes causing intimal thickening of the coronary arteries of human cardiac allografts $[4,5]$.

The anti-oxidant enzyme Heme Oxygenase (HO)-1 catalyzes the degradation of heme into biliverdin, iron 
and carbon monoxide (CO). Biliverdin is subsequently converted into bilirubin. These catabolic end products are thought to be responsible for the anti-inflammatory, antioxidant, and anti-apoptotic properties of HO-1 [6]. Upregulation of HO-1 might be a mechanism to protect cells from damage due to ischemia, reperfusion and inflammation $[6,7]$. Consequently HO-1 might prevent the induction of TCAD. Indeed, animal studies demonstrated that induction of HO-1 with an adenovirus-HO-1 construct or by cobalt protoporphyrin (CoPP) prior to or shortly after transplantation protects against the development of TCAD $[8,9]$.

\section{Objective}

To investigate whether HO-1 represents a factor by which the donor organ is protected from the initiation and progression of accelerated TCAD in human cardiac recipients, we measured intragraft mRNA expression levels of HO-1. In addition, we studied the mechanism by which HO-1 acts and therefore, we determined mRNA expression levels of Hypoxia Inducible Factor-(HIF) $1 \alpha$, a transcription factor for HO-1; TGF- $\beta$, a growth factor known to be involved in the development of TCAD $[4,10]$ and a regulator of HO-1 production [11]; FLIP (short and long), an anti-apoptotic marker of the TNF- $\alpha$-Fas/FasL induced apoptosis route and Bax and Bcl-2, pro- and anti-apoptotic markers of the mitochondrial apoptosis pathway. These parameters were measured in myocardial biopsies (MB) taken at the time of graft implantation (time 0), early after transplantation ( 1 week) and to the end of the first year after transplantation (10 months). Finally to establish the origin of HO-1, we performed immunohistochemical staining of HO-1 protein.

\section{Material and methods}

\subsection{Patients}

Intragraft mRNA expression of HO-1, HIF- $1 \alpha$, TGF- $\beta$, FLIP $_{\mathrm{S}+\mathrm{L}}, \mathrm{Bax}, \mathrm{Bcl}-2$ and 18S RNA (housekeeping gene) was studied in relation to accelerated TCAD. Therefore, myocardial biopsies (MB) from heart transplant recipients with and without early signs (at 1 year) of accelerated TCAD were selected. Coronary angiography was routinely performed at 1 year after transplantation for diagnosis of early signs of TCAD, which were defined as all abnormalities of the epicardial as well as the intramyocardial branches, including minimal wall irregularities observed by visual assessment of the coronary angiogram. Coronary arteriograms had been assessed long before mRNA measurements. An angiographic diagnosis was made by consensus of two observers with experience in the evaluation of post-transplant arteriograms [12]. Pre-transplant arterio- grams of the donors were not routinely performed and therefore not available.

MB were taken from the left ventricle at the end of graft implantation, before weaning from extra corporeal circulation (time 0 , without TCAD, $n=12$ and with TCAD, $n=11$ ), and from the right side of the interventricular septum early after transplantation (week 1 , without TCAD, $n=8$ and with TCAD, $n=8$ ) and during the development of TCAD (10 months after transplantation, without TCAD, $n=13$ and with TCAD, $n=14)$. All biopsies were free of signs for acute rejection (grade 0 or 1A, ISHLT criteria) [13]. Unfortunately, the studied biopsies were not all from a consistent cohort of patient. Biopsies of all three time-points were available from seven patients and of two time-points from 10 patients. Patient demographics at the different time points of mRNA measurements are summarized in Table 1. All patients were on Cyclosporine A and low dose steroids as maintenance immunosuppressive therapy. Cyclosporine A was aimed to keep $12 \mathrm{~h}$ through levels between 250 and $350 \mathrm{ng} / \mathrm{ml}$ in the first 6 months after transplantation and between 100 and $200 \mathrm{ng} / \mathrm{ml}$ after 6 months. Cytomegalovirus (CMV) infection was defined as any appearance of immunoglobulin $\mathrm{M}$ or isolation of CMV from urine, throat or blood or any demonstration of immediate early antigen. CMV disease was diagnosed when infection co-existed with two of the following symptoms: fever of more than $38{ }^{\circ} \mathrm{C}$ for at least two consecutive days, gastrointestinal, lung, retina or central nervous system involvement, leucopenia, thrombocytopenia, elevation of serum alanine or aspartate aminotransferases. CMV seronegative recipients received seronegative blood products and were, when receiving a heart of a seropositive donor, treated with anti-CMV hyperimmunoglobulins for passive immunization. All heart transplant recipients gave permission to use their material and data for research purposes.

\subsection{Total RNA extraction, cDNA synthesis and real-time polymerase chain reaction}

$\mathrm{MB}$ were snap-frozen in liquid nitrogen and stored at $-80{ }^{\circ} \mathrm{C}$ until use. Total RNA isolation and cDNA synthesis were performed as described previously [5]. The mRNA levels of HO-1, HIF- $1 \alpha$, TGF- $\beta$, FLIP, Bcl-2 and Bax and the RNA level of $18 \mathrm{~S}$ were measured using real-time PCR in the ABI Prism ${ }^{\circledR} 7700$ Sequence Detection System (Applied Biosystems, Foster City, CA, USA) as described in detail before [14]. For TGF- $\beta$ and $18 \mathrm{~S}$, pre-developed TaqMan ${ }^{\circledR}$ assays (Applied Biosystems) and for Bax and Bcl-2 primers and FRET probes (Biosource International, Camarillo, CA, USA) were used. For HO-1, HIF-1 $\alpha$ and FLIP (detecting both FLIP Snd $_{\mathrm{SLIP}}$ ) we designed the following primers and probes: $\mathrm{HO}-1$ sense primer: $5^{\prime}-\mathrm{TGC}$ TCA-ACA-TCC-AGC-TCT-TTG-A-3'; HO-1 anti-sense primer: 5'-GCA-GAA-TCT-TGC-ACT-TTG-TTG-CT-3'; HO-1 probe: FAM-5'-AGT-TGC-AGG-AGC-TGC-TGACCC-ATG-AC-3'; HIF-1 $\alpha$ sense primer: 5'-AAC-ATG- 
Table 1

Characteristics of patients at time points of intragraft mRNA expression measurement

\begin{tabular}{|c|c|c|c|c|c|c|c|c|c|}
\hline & \multicolumn{3}{|c|}{ Before transplantation } & \multicolumn{3}{|l|}{ Week 1} & \multicolumn{3}{|l|}{ Month 10} \\
\hline & $\begin{array}{l}\text { TCAD } \\
\text { neg } n=12\end{array}$ & $\begin{array}{l}\text { TCAD } \\
\operatorname{pos} n=11\end{array}$ & p-value & $\begin{array}{l}\text { TCAD } \\
\text { neg } n=8\end{array}$ & $\begin{array}{l}\text { TCAD } \\
\operatorname{pos} n=8\end{array}$ & p-value & $\begin{array}{l}\text { TCAD } \\
\text { neg } n=13\end{array}$ & $\begin{array}{l}\text { TCAD } \\
\text { pos } n=14\end{array}$ & p-value \\
\hline Recipient age (years) ${ }^{\mathrm{a}}$ & $\begin{array}{l}54.0 \\
(19.2-65.2)\end{array}$ & $\begin{array}{l}57.3 \\
(14.2-65.3)\end{array}$ & $0.83^{\mathrm{b}}$ & $\begin{array}{l}54.0 \\
(19.2-61.9)\end{array}$ & $\begin{array}{l}56.3 \\
(41.9-61.3)\end{array}$ & $0.80^{\mathrm{b}}$ & $\begin{array}{l}52.2 \\
(19.2-65.0)\end{array}$ & $\begin{array}{l}55.2 \\
(14.2-63.7)\end{array}$ & $0.56^{\mathrm{b}}$ \\
\hline Donor age (years) ${ }^{\mathrm{a}}$ & $\begin{array}{l}31.5 \\
(13.0-52.0)\end{array}$ & $\begin{array}{l}38.0 \\
(17.0-49.0)\end{array}$ & $0.21^{\mathrm{b}}$ & $\begin{array}{l}32.5 \\
(13.0-43.0)\end{array}$ & $\begin{array}{l}40.5 \\
(31.0-49.0)\end{array}$ & $0.07^{\mathrm{b}}$ & $\begin{array}{l}34.0 \\
(22.0-52.0)\end{array}$ & $\begin{array}{l}36.0 \\
(17.0-49.0)\end{array}$ & $0.96^{\mathrm{b}}$ \\
\hline Recipient gender $(\mathrm{M} / \mathrm{F})$ & $11 / 1$ & $9 / 2$ & $0.59^{\mathrm{c}}$ & $7 / 1$ & $7 / 1$ & $1.0^{\mathrm{c}}$ & $13 / 0$ & $12 / 2$ & $0.48^{\mathrm{c}}$ \\
\hline Donor gender $(\mathrm{M} / \mathrm{F})$ & $7 / 5$ & $5 / 6$ & $0.68^{\mathrm{c}}$ & $7 / 1$ & $4 / 4$ & $0.28^{\mathrm{c}}$ & $7 / 6$ & $5 / 9$ & $0.45^{\mathrm{c}}$ \\
\hline $\begin{array}{l}\text { Gender mismatch } \\
\text { (no/yes) }\end{array}$ & $6 / 6$ & $7 / 4$ & $0.68^{\mathrm{c}}$ & $6 / 2$ & $5 / 3$ & $1.0^{\mathrm{c}}$ & $7 / 6$ & $7 / 7$ & $1.0^{\mathrm{c}}$ \\
\hline $\begin{array}{l}\text { Cause of braindeath } \\
\text { (donor) Cerebrovascular/ } \\
\text { trauma/unknown }\end{array}$ & $7 / 4 / 1$ & $6 / 5 / 0$ & $0.68^{\mathrm{c}}$ & $4 / 3 / 1$ & $5 / 3 / 0$ & $1.0^{\mathrm{c}}$ & $7 / 5 / 1$ & $6 / 7 / 1$ & $0.84^{\mathrm{c}}$ \\
\hline $\begin{array}{l}\text { Time of brain death of } \\
\text { donor (min)* }\end{array}$ & $\begin{array}{l}619 \\
(387-920)\end{array}$ & $\begin{array}{l}538 \\
(167-810)\end{array}$ & $0.19^{\mathrm{b}}$ & $\begin{array}{l}598 \\
(387-920)\end{array}$ & $\begin{array}{l}529 \\
(390-810)\end{array}$ & $0.78^{\mathrm{b}}$ & $\begin{array}{l}595 \\
(390-920)\end{array}$ & $\begin{array}{l}535 \\
(217-810)\end{array}$ & $0.12^{\mathrm{b}}$ \\
\hline $\begin{array}{l}\text { Vasoactive drugs in donor } \\
\text { (no/yes/unknown) }\end{array}$ & $2 / 9 / 1$ & $0 / 11 / 0$ & $0.34^{\mathrm{c}}$ & $2 / 6 / 0$ & $0 / 8 / 0$ & $0.47^{\mathrm{c}}$ & $1 / 11 / 1$ & $0 / 12 / 2$ & $1.0^{\mathrm{c}}$ \\
\hline $\begin{array}{l}\text { Heart disease (recipient) } \\
\text { CMP/IHD/other }\end{array}$ & $4 / 7 / 1$ & $2 / 8 / 1$ & $0.80^{\mathrm{c}}$ & $5 / 3 / 0$ & $1 / 6 / 1$ & $0.12^{\ddagger}$ & $4 / 8 / 1$ & $4 / 8 / 1$ & $1.0^{\mathrm{c}}$ \\
\hline Cold ischemia time $(\mathrm{min})^{\mathrm{a}}$ & $\begin{array}{l}171 \\
(136-197)\end{array}$ & $\begin{array}{l}190 \\
(127-220)\end{array}$ & $0.37^{\mathrm{b}}$ & $\begin{array}{l}173 \\
(140-197)\end{array}$ & $\begin{array}{l}178 \\
(140-279)\end{array}$ & $0.54^{\mathrm{b}}$ & $\begin{array}{l}171 \\
(110-245)\end{array}$ & $\begin{array}{l}178 \\
(128-279)\end{array}$ & $0.46^{\mathrm{b}}$ \\
\hline HLA AB mismatches ${ }^{a}$ & $\begin{array}{l}3.0 \\
(2.0-4.0)\end{array}$ & $\begin{array}{l}3.0 \\
(2.0-4.0)\end{array}$ & $0.15^{\mathrm{b}}$ & $\begin{array}{l}3.0 \\
(2.0-4.0)\end{array}$ & $\begin{array}{l}4.0 \\
(2.0-4.0)\end{array}$ & $0.50^{\mathrm{b}}$ & $\begin{array}{l}3.0 \\
(2.0-4.0)\end{array}$ & $\begin{array}{l}3.0 \\
(1.0-4.0)\end{array}$ & $0.33^{\mathrm{b}}$ \\
\hline HLA-DR mismatches ${ }^{a}$ & $\begin{array}{l}2.0 \\
(0.0-2.0)\end{array}$ & $\begin{array}{l}2.0 \\
(0.0-2.0)\end{array}$ & $0.78^{\mathrm{b}}$ & $\begin{array}{l}2.0 \\
(0.0-2.0)\end{array}$ & $\begin{array}{l}2.0 \\
(0.0-2.0)\end{array}$ & $0.72^{\mathrm{b}}$ & $\begin{array}{l}2.0 \\
(0.0-2.0)\end{array}$ & $\begin{array}{l}2.0 \\
(0.0-2.0)\end{array}$ & $0.55^{\mathrm{b}}$ \\
\hline $\begin{array}{l}\text { Induction therapy } \\
\text { None/anti-T-cell/ } \\
\text { anti-CD25 }\end{array}$ & $1 / 7 / 4$ & $2 / 5 / 4$ & $0.86^{\mathrm{c}}$ & $0 / 5 / 3$ & $1 / 5 / 2$ & $1.0^{\mathrm{c}}$ & $3 / 9 / 1$ & $3 / 8 / 3$ & $0.75^{\mathrm{c}}$ \\
\hline $\mathrm{Nr}$ of AR first year ${ }^{\mathrm{a}}$ & $\begin{array}{l}1.0 \\
(0.0-4.0)\end{array}$ & $\begin{array}{l}4.0 \\
(0.0-5.0)\end{array}$ & $0.04^{\mathrm{b}}$ & $\begin{array}{l}1.0 \\
(0.0-3.0)\end{array}$ & $\begin{array}{l}1.5 \\
(0.0-5.0)\end{array}$ & $0.57^{\mathrm{b}}$ & $\begin{array}{l}1.0 \\
(0.0-3.0)\end{array}$ & $\begin{array}{l}2.0 \\
(0.0-5.0)\end{array}$ & $0.33^{\mathrm{b}}$ \\
\hline CMV infection (no/yes) & $9 / 3$ & $5 / 6$ & $0.21^{\ddagger}$ & $7 / 1$ & $4 / 4$ & $0.28^{\mathrm{c}}$ & $8 / 5$ & $8 / 6$ & $1.0^{\mathrm{c}}$ \\
\hline CMV disease (no/yes) & $10 / 2$ & $9 / 2$ & $1.0^{\mathrm{c}}$ & $8 / 0$ & $6 / 2$ & $0.47^{\mathrm{c}}$ & $9 / 4$ & $9 / 5$ & $1.0^{\mathrm{c}}$ \\
\hline $\begin{array}{l}\text { Total cholesterol at 1-year } \\
(\mathrm{nmol} / \mathrm{L})^{\mathrm{a}}\end{array}$ & $\begin{array}{l}7.0 \\
(4.0-9.9)\end{array}$ & $\begin{array}{l}6.5 \\
(4.3-11.0)\end{array}$ & $0.73^{\mathrm{b}}$ & $\begin{array}{l}5.1 \\
(4.0-9.1)\end{array}$ & $7.4(4.7-11.0)$ & $0.23^{\mathrm{b}}$ & $\begin{array}{l}6.4 \\
(4.8-9.1)\end{array}$ & $\begin{array}{l}6.4 \\
(4.7-11.0)\end{array}$ & $0.98^{\mathrm{b}}$ \\
\hline $\begin{array}{l}\text { Triglycerides at } 1 \text {-year } \\
(\mathrm{nmol} / \mathrm{L})^{\mathrm{a}}\end{array}$ & $\begin{array}{l}2.1 \\
(0.7-4.4)\end{array}$ & $\begin{array}{l}2.9 \\
(1.3-4.8)\end{array}$ & $0.48^{\mathrm{b}}$ & $\begin{array}{l}2.0 \\
(0.7-2.4)\end{array}$ & $2.6(0.9-3.2)$ & $0.34^{\mathrm{b}}$ & $\begin{array}{l}2.8 \\
(1.2-5.8)\end{array}$ & $\begin{array}{l}2.1 \\
(0.9-3.2)\end{array}$ & $0.10^{\mathrm{b}}$ \\
\hline $\begin{array}{l}\text { HMG-CoA-reductase } \\
\text { inhibitors (no/yes) }\end{array}$ & $10 / 2$ & $11 / 0$ & $0.48^{\mathrm{c}}$ & $6 / 2$ & $8 / 0$ & $0.47^{\mathrm{c}}$ & $9 / 4$ & $11 / 3$ & $0.68^{\mathrm{c}}$ \\
\hline
\end{tabular}

TCAD was diagnosed at 1 year.

AR: acute rejection, CMP: dilated cardiomyopathy, IHD: ischemic heart disease. Time of brain death of the donor: from establishment of brain death to the harvesting of the heart.

${ }^{\mathrm{a}}$ Median with range between parentheses.

${ }^{\mathrm{b}} p$-values are obtained by Mann-Whitney test.

${ }^{c} p$-values are obtained by (exact) $\chi^{2}$-test.

ATG-GTT-CAC-TTT-TTC-AAG-C-3'; HIF-1 $\alpha$ anti-sense primer: 5'-GTC-AGC-TGT-GGT-AAT-CCA-CTT-TCA-T3'; HIF-1 $\alpha$ probe: FAM-5'-TAG-GAA-TTG-GAA-CATTAT-TAC-AGC-AGC-CAG-ACG-3'; FLIP sense primer: 5'-AGG-CAA-GAT-AAG-CAA-GGA-GAA-GAG-T-3'; FLIP anti-sense primer: 5'-TTT-TCT-ATT-AAA-TCC-AGTTGA-TCT-GGG-3'; FLIP probe: FAM-5'-TCT-TGG-ACCTTG-TGG-TTG-AGT-TGG-AGA-AA- $3^{\prime}$. PCR conditions were: incubation at $50{ }^{\circ} \mathrm{C}$ for $10 \mathrm{~min}$ to enable Uracil $\mathrm{N}$-glycosylase (present in the mastermix) to destroy possible amplicons, incubation at $95{ }^{\circ} \mathrm{C}$ for $10 \mathrm{~min}$ to activate AmpliTaq Gold polymerase followed by 40 cycles of $15 \mathrm{sec}$ denaturation at $95{ }^{\circ} \mathrm{C}$ and $1 \mathrm{~min}$ annealing and extension at optimal temperatures $\left(59{ }^{\circ} \mathrm{C}\right.$ for HO-1, HIF-
$1 \alpha$ and $\operatorname{FLIP}\left({ }_{\mathrm{S}+\mathrm{L}}\right)$ and $60{ }^{\circ} \mathrm{C}$ for TGF- $\beta, \mathrm{Bcl}-2$, Bax, and 18S). Standard curves with serial dilutions of known amounts of the target molecules were used to determine the mRNA concentrations in MB. The measured mRNA concentrations for the different molecules were standardized for the $18 \mathrm{~S}$ concentration.

\subsection{Immunohistochemical analysis}

Double staining of HO-1 with CD3 (T-cells), CD68 (macrophages) and CD31 (endothelial cells) was performed on snap frozen MB specimens ( $n=12$, taken at week 1$)$, cut in $5 \mu \mathrm{m}$ sections, air-dried and fixed for $10 \mathrm{~min}$ in acetone. The primary antibodies used to stain the samples were 
rabbit-anti-human (HO-1: clone H-105, Santa Cruz, Biotechnology, Santa Cruz, CA) and mouse-anti-human (CD3: clone SK7, Becton and Dickinson, San Jose, CA; CD68: clone KP1 and CD31: clone JC/70A Dako, Glostrup, Denmark). Optimal working dilutions for the antibodies were previously determined by titration assays. For the detection of HO-1, we used the ABC method and the PAP method for CD3, CD68 and CD31. In brief, slides were rinsed in phosphate-buffered saline (PBS) and incubated with rabbit-anti-human or mouse anti-human antibodies for $30 \mathrm{~min}$ at RT. The slides were then rinsed twice with PBS and incubated with biotinylated goat-anti-rabbit antibody (HO-1; Dako) or rabbit-anti-mouse IgG (CD3, CD68 and CD31; Biogenex, San Ramon CA) for $30 \mathrm{~min}$. The slides were rinsed with Tris- $\mathrm{HCl} \mathrm{pH} 8$ and subsequently labeled with the ABC complex or PAP complex. The enzyme was detected with Fast Blue BB Salt (HO-1; Sigma-Aldrich, Zwijndrecht, The Netherlands) or DAB (CD3, CD68 and CD31; Sigma) as a substrate, following the manufacturers instructions. In control sections, the primary antibody was omitted.

\subsection{Statistics}

Characteristics of patients with and without TCAD were compared using the (exact) $\chi^{2}$-test for discrete variables and Mann-Whitney or Student's $t$-test for continues variables, as appropriate. When the exact $\chi^{2}$-test was used, the exact mid $p$-value was calculated, using StatXact software (CYTEL Software, Cambridge, MA, USA).

To compare mRNA expression levels between patients with and without TCAD at the different time points, the Mann-Whitney test was used. For all tests, $p \leq 0.05$ was considered significant.

\section{Results}

\subsection{Patient demographics}

The characteristics of recipients with and without accelerated TCAD were comparable at all time points of mRNA measurements, except for the number of acute rejections at time 0 (Table 1). This was higher in the recipients in which early signs of TCAD were observed at 1 year.

\subsection{Intragraft $m R N A$ expression}

No differences in mRNA expression levels of any of the measured parameters were found between patients without $(n=12)$ and with $(n=11)$ accelerated TCAD in the time 0 biopsies (Table 2, Fig. 1A, HO-1; 1B, TGF- $\beta$; 1C, Bcl-2/ Bax). At 1 week, however, higher mRNA expression levels for HO-1 and TGF- $\beta$ in biopsies from patients with TCAD compared to grafts of patients without TCAD were found

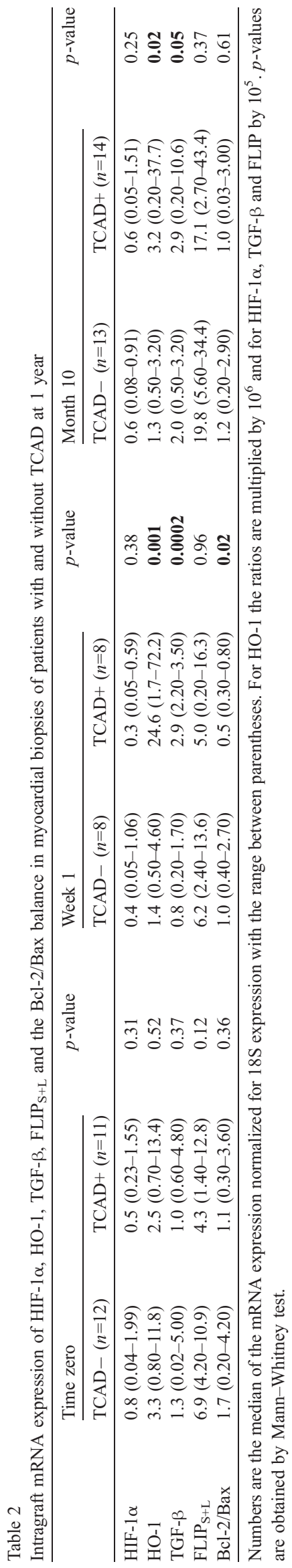



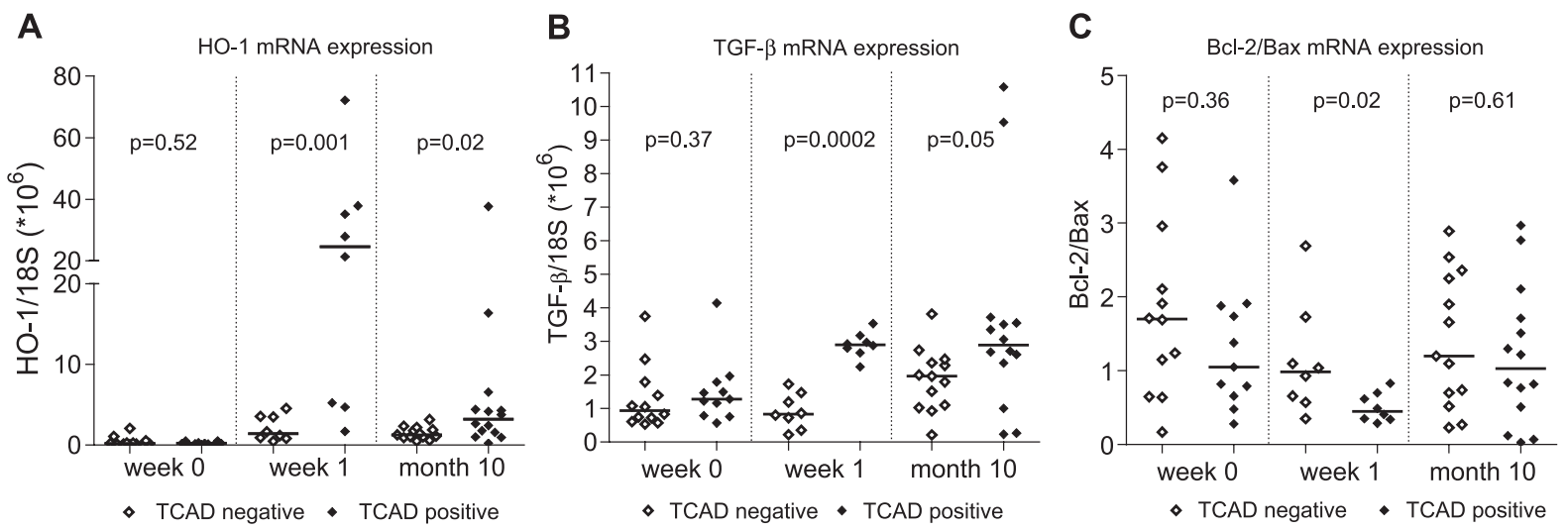

Fig. 1. Intragraft mRNA expression at week 1 and month 10 after transplantation of Heme-Oxygenase-1 and TGF- $\beta$ (A and C) and apoptotic markers FLIP and $\mathrm{Bcl}-2 / \mathrm{Bax}$ ratio (B and D) in patients with and without transplant coronary artery disease (TCAD). A significant higher mRNA expression for HO- 1 and TGF- $\beta$ accompanied by a pro-apoptotic shift in the Bcl-2/Bax balance at 1 week after transplantation was found in patients with TCAD. The higher HO-1 and TGF- $\beta$ levels were again found at 10 months in TCAD positive patients.

(Table 2 and Fig. 1A, HO-1 and 1B, TGF- $\beta$ ). In addition, we found a lower ratio of the apoptotic markers Bcl-2/Bax in patients with signs of TCAD (Table 2, Fig. 1C). The HIF-1 $\alpha$ mRNA expression levels were comparable between the patient groups (Table 2) and also no differences for FLIP between the two patient groups were measured (Table 2). In biopsies taken at 10 months after transplantation, again, higher HO-1 and TGF- $\beta$ mRNA expression levels were measured in patients with a positive coronary angiogram (Table 2, Fig. 1A, HO-1 and 1B, TGF- $\beta$ ). In these samples, no differences in apoptotic markers were detected between patients with or without TCAD (Table 2, Fig. 1C, Bcl-2/Bax) and comparable HIF-1 $\alpha$ expression was found (Table 2).

In Fig. 2, we show the HO-1 mRNA expression over time, with a connecting line between biopsies of one patient. The consistent cohort of patients was too small for statistical analysis, but an increased HO-1 mRNA expression was observed in TCAD positive patients at week 1 that

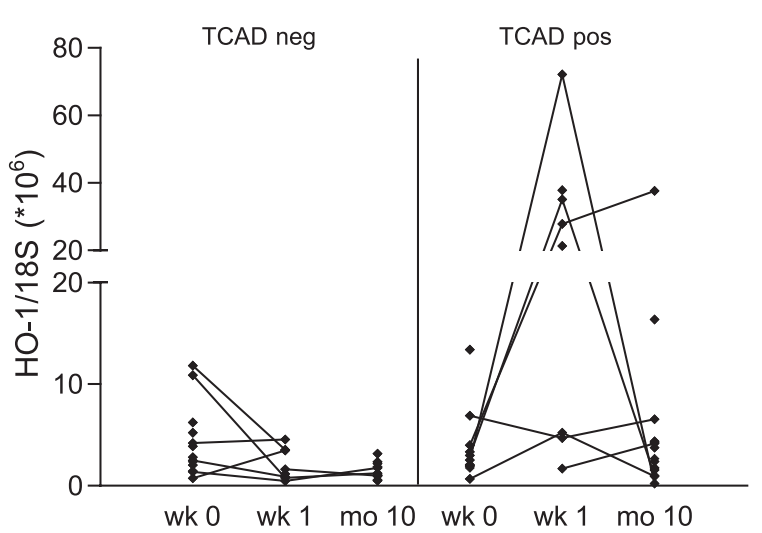

Fig. 2. Intragraft Heme Oxygenase-1 mRNA expression in patients with and without TCAD over time. The connected dots are biopsies from 1 patient. Week 0: time point at time of transplantation, week 1: 1 week after transplantation, month 10: 10 months after transplantation. decreased thereafter. We did not observe this in TCAD negative cardiac recipients.

\subsection{Immunohistochemical analysis}

Because of subjectivity in quantifying immunohistochemical results, we only used this technique to determine the origin of the HO-1 production. We studied week 1 biopsies, because the differences in mRNA expression between patients with and without TCAD was most striking at this time point. Only a few CD3 (T-cells) positive cells were present in the biopsies. These CD3 cells did not express HO-1. Of the CD31 (endothelial cells) positive cells, a few cells were positive for HO-1 $(<10 \%)$. HO-1 expression was mainly seen in CD68 (macrophages) positive cells (Fig. 3).

All biopsies $(n=12)$ contained CD68 positive cells (range 11-100 cells), which was in accordance with previous findings [15]. In eight of these biopsies, $50-90 \%$ of the macrophages expressed HO-1. No double staining for HO-1 and cardiomyocytes was performed, but morphological analysis of the biopsies showed no HO-1 positive cardiomyocytes.

\section{Discussion}

We investigated HO-1 expression and a possible way by which HO-1 acts in the initiation and progression of accelerated TCAD. We measured higher HO- 1 and TGF- $\beta$ mRNA expression levels in biopsies taken from recipients with early angiographic signs of TCAD compared to patients without TCAD at both 1 week and at 10 months after transplantation. In the week 1 biopsies, these higher expression levels were accompanied by a shifted Bcl-2/Bax balance towards the pro-apoptotic marker Bax of the mitochondrial apoptosis pathway. This indicates that these patients might be prone to apoptosis and tissue injury due to apoptosis via this route. 

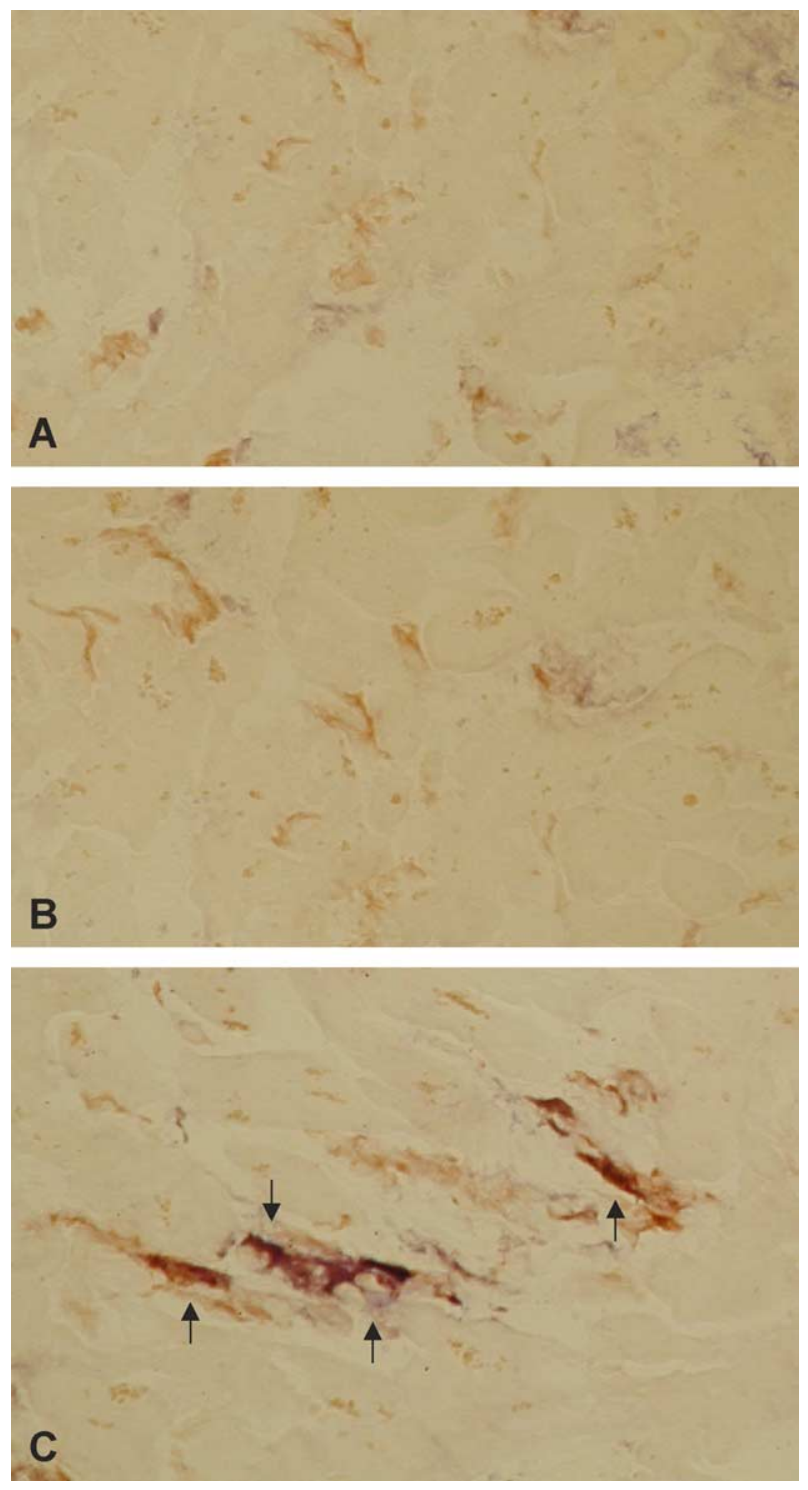

Fig. 3. Immunohistochemical double staining $(40 \times)$ of (A) HO-1 (blue) and CD3 (T-cells, brown), (B) HO-1 and CD31 (endothelial cells, brown), (C) HO-1 and CD68 (macrophages, brown) and the negative control (primary antibody omitted) in myocardial biopsies from TCAD positive patients at 1 week post-transplantation. HO-1 expression is mainly seen in CD68 positive cells.

The higher HO-1 mRNA expression levels in patients who developed TCAD within the first year was unexpected. In accordance with the findings in rodents, we presumed that HO-1 would have been higher in TCAD negative heart transplant recipients [8,9]. Apparently, despite upregulation of HO-1, accelerated TCAD developed in our patients. However, also in another human study, in kidney transplant patients, higher HO-1 mRNA expression was found in biopsies from patients with acute rejection compared to patients without. Like in our patients, a higher HO-1 level seemed not to be protective [7]. Moreover, in the animal studies, production of HO-1 was induced in the donor organ before transplantation with CoPP or an adenovirus construct containing HO-1. In our study, there was no artificial upregulation of HO-1 in the donor heart. In the biopsies of our heart transplant recipients, HO-1 induction could have been caused by cellular stress, such as hypoxia, ischemia/ reperfusion and inflammation [16-19]. Hypoxia activates the transcription factors HIF- $1 \alpha, \mathrm{NF} \kappa \mathrm{B}$ and AP-1 which subsequently lead to the upregulation of HO-1 $[16,20,21]$. However, the higher HO-1 expression was not associated with upregulation of HIF- $1 \alpha$, suggesting that this transcription factor is not the initiator of the HO-1 production in our patient group. Reperfusion after a period of ischemia might also lead to upregulation of HO-1. During reperfusion, an oxygen burst occurs, whereby reactive oxygen species (ROS) are formed [17,22-24]. ROS activate transcription factors, which then can induce expression of proinflammatory cytokines leading to inflammatory responses. HO-1 is able to suppress inflammatory reactions [19]. Indeed, our immunohistochemical results show that most of the HO-1 protein is produced by the infiltrating macrophages. This suggests that HO-1 is upregulated as an adaptive response and probably plays a role in the resolution of the inflammatory responses. Because of the subjectivity of quantifying immunohistochemical stainings, we did not determine the correlation between the mRNA expression levels and the HO-1 protein production by the macrophages.

ROS can also cause tissue damage by inducing mitochondrial membrane changes, leading to the release of apoptogenic factors, which is promoted by Bax and prevented by Bcl-2 [22-25]. Although, we cannot exclude that the Bcl-2 and Bax is produced by infiltrating macrophages and T-cells, we assume that the balance between Bcl-2 and Bax might reflect tissue injury due to apoptosis and the found pro-apoptotic shift in the 1 week biopsies suggests more tissue damage and, thus, more inflammation in patients who were going to develop TCAD. In this view, as mentioned before, the higher HO-1 mRNA expression might be a response to the injury.

We also confirmed earlier findings of our group that more TGF- $\beta$ mRNA is expressed in biopsies from patients with early signs of TCAD [5]. Since it is known that TGF- $\beta$ is involved in wound repair, we assume that TGF- $\beta$ is upregulated to repair damaged tissue due to peri-operative processes. Upregulation of HO- 1 by TGF- $\beta$ might be a mechanism to govern the repair process [11].

The differential HO-1 expression between patients with and without TCAD might also be influenced by the administered immunosuppressive drugs. For example, steroids inhibit activation of $\mathrm{NF} \kappa \mathrm{B}$, which is a transcription factor for HO-1 and, thus, might influence HO-1 expression $[26,27]$. However, the patients received similar immunosuppressive regimen.

The above considerations only explain the upregulation of HO-1 as an adaptive inflammatory response to avoid or limit oxidative damage. However, it does not explain why there might be more damage in some donor hearts compared to others. Therefore, we compared donor factors that might contribute to graft injury, like time of and cause of brain 
death of the donor or use of vasoactive drugs in the donor. This did also not clarify the question, as we could not find a relation between these parameters and development of TCAD.

We are aware of the limitations of our study. Our patient groups are small and the biopsies taken at the different time points do not reflect a consistent cohort of patients. We performed a retrospective study in which we selected the most optimal patient groups with a maximum number of available biopsies of the chosen time-points. Nevertheless, consistent data for HO-1, TGF- $\beta$ and Bcl-2/Bax balance were generated. Furthermore, visual angiographic assessment of the coronary arteries instead of intravascular ultrasound (IVUS) was used to define the presence of abnormalities in the coronary arteries. Visual assessment of angiograms is less sensitive as only the contrast filled lumen is assessed. Measurements of vessel wall abnormalities by IVUS would have been preferable. Unfortunately, such procedure is not routinely performed at our institution. Although our preliminary results should be confirmed in a prospective study with a consistent cohort of patients, we think that our findings are important, because there is only limited data of HO-1 expression in human tissue and a clinical setting available. We conclude that HO-1 expression is upregulated in grafts with early signs of TCAD compared to patients who develop TCAD later after transplantation. It is not clear whether the increase in HO-1 mRNA expression is the cause or the consequence of TCAD, but our data suggest that upregulation of $\mathrm{HO}-1$ is an adaptive response to limit cell and tissue injury and a subsequent inflammation process. The overexpression of HO-1 might therefore be a reflection of damage due to the transplantation procedure and the subsequent inflammatory response.

\section{References}

[1] Hertz MI, Taylor DO, Trulock EP, Boucek MM, Mohacsi PJ, Edwards LB, et al. The registry of the international society for heart and lung transplantation: nineteenth official report-2002. J Heart Lung Transplant 2002;21(9):950-70.

[2] Vassalli G, Gallino A. Endothelial dysfunction and accelerated coronary artery disease in cardiac transplant recipients. Microcirculation Working Group, European Society of Cardiology. Eur Heart J 1997;18(11):1712-7.

[3] Day JD, Rayburn BK, Gaudin PB, Baldwin III WM, Lowenstein CJ, Kasper EK, et al. Cardiac allograft vasculopathy: the central pathogenetic role of ischemia-induced endothelial cell injury. J Heart Lung Transplant 1995;14(6 Pt. 2):S142-9.

[4] Paul LC. Growth factors in chronic rejection. Transplant Sci 1993;3:113-7.

[5] de Groot-Kruseman HA, Baan CC, Mol WM, Niesters HG, Maat AP, Balk $\mathrm{AH}$, et al. Intragraft platelet-derived growth factor-alpha and transforming growth factor-beta1 during the development of accelerated graft vascular disease after clinical heart transplantation. Transpl Immunol 1999;7(4):201-5.

[6] Katori M, Busuttil RW, Kupiec-Weglinski JW. Heme oxygenase-1 system in organ transplantation. Transplantation 2002;74(7):905-12.

[7] Avihingsanon Y, Ma N, Csizmadia E, Wang C, Pavlakis M, Giraldo $\mathrm{M}$, et al. Expression of protective genes in human renal allografts: a regulatory response to injury associated with graft rejection. Transplantation 2002;73(7):1079-85.

[8] Bouchet D, Chauveau C, Roussel JC, Mathieu P, Braudeau C, Tesson $\mathrm{L}$, et al. Inhibition of graft arteriosclerosis development in rat aortas following heme oxygenase-1 gene transfer. Transpl Immunol 2002; 9(2-4):235-8

[9] Hancock WW, Buelow R, Sayegh MH, Turka LA. Antibodyinduced transplant arteriosclerosis is prevented by graft expression of anti-oxidant and anti-apoptotic genes. Nat Med 1998;4(12): 1392-6.

[10] Raisanen-Sokolowski A, Hayry P. Chronic allograft arteriosclerosis: contributing factors and molecular mechanisms in the light of experimental studies. Transpl Immunol 1996;4(2):91-8.

[11] Ning W, Song R, Li C, Park E, Mohsenin A, Choi AM, et al. TGFbeta(1) stimulates $\mathrm{HO}-1$ via the $\mathrm{p} 38$ mitogen-activated protein kinase in A549 pulmonary epithelial cells. Am J Physiol, Lung Cell Mol Physiol 2002;283(5):L1094-102.

[12] Balk AH, Simoons ML, van der Linden MJ, de Feyter PJ, Mochtar B, Weimar W, et al. Coronary artery disease after heart transplantation: timing of coronary arteriography. J Heart Lung Transplant 1993; 12:89-99.

[13] Billingham ME, Cary NR, Hammond ME, Kemnitz J, Marboe C, McCallister HA, et al. A working formulation for the standardization of nomenclature in the diagnosis of heart and lung rejection: Heart Rejection Study Group. The International Society for Heart Transplantation. J Heart Transplant 1990;9(6):587-93.

[14] Baan CC, van Riemsdijk-van Overbeeke IC, Balk AH, Vantrimpont WM, Mol WM, Knoop CJ, et al. Conversion from cyclosporin A to tacrolimus is safe and decreases blood pressure, cholesterol levels and TGF-beta 1 type I receptor expression. Clin Transplant 2001;15(4): $276-83$.

[15] Baan CC, Knoop CJ, van Gelder T, van der Ham F, Zondervan PE, Holweg CT, et al. Contribution of the inflammatory response to cardiac allograft rejection: histopathologic analysis of serial endomyocardial biopsies. Transplant Proc 1998;30(4):1104-6.

[16] Lee PJ, Jiang BH, Chin BY, Iyer NV, Alam J, Semenza GL, et al. Hypoxia-inducible factor-1 mediates transcriptional activation of the heme oxygenase- 1 gene in response to hypoxia. J Biol Chem 1997;272(9):5375-81.

[17] Foresti R, Goatly H, Green CJ, Motterlini R. Role of heme oxygenase1 in hypoxia-reoxygenation: requirement of substrate heme to promote cardioprotection. Am J Physiol, Heart Circ Physiol 2001; 281(5):H1976-84.

[18] Otterbein LE, Choi AM. Heme oxygenase: colors of defense against cellular stress. Am J Physiol, Lung Cell Mol Physiol 2000;279(6): L1029-37.

[19] Elbirt KK, Bonkovsky HL. Heme oxygenase: recent advances in understanding its regulation and role. Proc Assoc Am Physicians 1999;111(5):438-47.

[20] Lavrovsky Y, Schwartzman ML, Levere RD, Kappas A, Abraham NG. Identification of binding sites for transcription factors NFkappa B and AP-2 in the promoter region of the human heme oxygenase 1 gene. Proc Natl Acad Sci U S A 1994;91(13): $5987-91$

[21] Natarajan R, Fisher BJ, Jones DG, Ghosh S, Fowler III AA. Reoxygenating microvascular endothelium exhibits temporal dissociation of NF-kappaB and AP-1 activation. Free Radic Biol Med 2002;32(10): $1033-45$.

[22] Jurgensmeier JM, Xie Z, Deveraux Q, Ellerby L, Bredesen D, Reed JC. Bax directly induces release of cytochrome $\mathrm{c}$ from isolated mitochondria. Proc Natl Acad Sci U S A 1998;95(9):4997-5002.

[23] Yang J, Liu X, Bhalla K, Kim CN, Ibrado AM, Cai J, et al. Prevention of apoptosis by $\mathrm{Bcl}-2$ : release of cytochrome c from mitochondria blocked. Science 1997;275(5303):1129-32.

[24] Jassem W, Fuggle SV, Rela M, Koo DD, Heaton ND. The role of mitochondria in ischemia/reperfusion injury. Transplantation 2002; 73(4):493-9. 
[25] Li P, Nijhawan D, Budihardjo I, Srinivasula SM, Ahmad M, Alnemri ES, et al. Cytochrome c and dATP-dependent formation of Apaf-1/ caspase-9 complex initiates an apoptotic protease cascade. Cell 1997;91(4):479-89.

[26] Auphan N, DiDonato JA, Rosette C, Helmberg A, Karin M. Immunosuppression by glucocorticoids: inhibition of NF-kappa B activity through induction of I kappa B synthesis. Science 1995;270(5234):286-90.

[27] Hancock WW. Impact of alloimmunity on chronic tissue remodelling: role of cytokines and protective genes in the vessel wall. Transplant Immunol 1997;5(4):277-81. 